\title{
Assessment of Exposure Due to Technologically Enhanced Natural Radioactivity in Various Samples of Moroccan Building Materials
}

\author{
Bouchaib Kassi', Aziz Boukhair ${ }^{1,2 *}$, Khadija Azkour ${ }^{3}$, Mohamed Fahad', \\ Mohammed Benjelloun ${ }^{1}$, Abdel-Mjid Nourreddine ${ }^{4}$ \\ ${ }^{1}$ Laboratory of Physics and Nuclear Techniques, Atomic and Molecular, Chouaib Doukkali University, El Jadida, Morocco \\ ${ }^{2}$ Regional Center of the Trades of Education and Training, El Jadida, Morocco \\ ${ }^{3}$ Ministère de l'Intérieur, El Jadida, Morocco \\ ${ }^{4}$ Groupe RaMsEs, Institut Pluridisciplinaire Hubert Curien (IPHC), Université de Strasbourg, Strasbourg, France \\ Email: *mouad.boukhair@gmail.com
}

How to cite this paper: Kassi, B., Boukhair, A., Azkour, K., Fahad, M., Benjelloun, M. and Nourreddine, A.-M. (2018) Assessment of Exposure Due to Technologically Enhanced Natural Radioactivity in Various Samples of Moroccan Building Materials. World Journal of Nuclear Science and Technology, 8, 176-189. https://doi.org/10.4236/wjnst.2018.84015

Received: September 10, 2018

Accepted: October 19, 2018

Published: October 22, 2018

Copyright (c) 2018 by authors and Scientific Research Publishing Inc. This work is licensed under the Creative Commons Attribution International License (CC BY 4.0).

http://creativecommons.org/licenses/by/4.0/

\section{(c) (i) Open Access}

\begin{abstract}
The aim of our present work is to measure the specific activities of the radionuclides ${ }^{226} \mathrm{Ra},{ }^{232} \mathrm{Th},{ }^{40} \mathrm{~K}$ and the exhalation rates in terms of area and mass of ${ }^{222} \mathrm{Rn}$ in some samples of building materials commonly used in Morocco in order to evaluate the radiological risk caused by natural radioactivity. To this end, the analyses were carried out, using two nuclear techniques, namely high resolution gamma spectrometry and alpha dosimetry based on the use of LR115, on 50 samples collected from large commercial suppliers in Morocco. The results of these analyses show that the average specific activities of ${ }^{226} \mathrm{Ra}$, ${ }^{232} \mathrm{Th}$ and ${ }^{40} \mathrm{~K}$ in these materials vary from 9 to $52 \mathrm{~Bq} / \mathrm{kg}, 3$ to $63 \mathrm{~Bq} / \mathrm{kg}$ and 68 to $705 \mathrm{~Bq} / \mathrm{kg}$ respectively. These activities remain within the permissible limits of $35 \mathrm{~Bq} / \mathrm{kg}, 30 \mathrm{~Bq} / \mathrm{kg}$ and $370 \mathrm{~Bq} / \mathrm{kg}$ respectively, with the exception of a few samples of red brick, gray cement, ceramic and granite. The activity of the radium equivalent $\left(R a_{e q}\right)$, the internal $\left(H_{i n}\right)$ and external $\left(H_{e x}\right)$ hazard indices, the absorbed dose rate $(\dot{D})$, the total annual effective dose $\left(\dot{E}_{\text {tot }}\right)$, the excess lifetime cancer risk (ELCR) as well as volumic activities, exhalation rates in terms of area $\left(E_{S}\right)$ and mass $\left(E_{M}\right)$ are calculated for the samples analyzed in this work in order to assess the radiological risks resulting from the use of these materials in various construction activities. It seems that the values of these indices vary from 19 to $196 \mathrm{~Bq} / \mathrm{kg}, 0.08$ to $0.67,0.05$ to $0.53,9$ to $91 \mathrm{nGy} / \mathrm{h}, 0.05$ to $0.56 \mathrm{mSv} / \mathrm{y}, 0.19 \times 10^{-3}$ to $1.96 \times 10^{-3}, 72$ to $350 \mathrm{~Bq} / \mathrm{m}^{3}, 56$ to $273 \mathrm{mBq} \cdot \mathrm{m}^{-2} \cdot \mathrm{h}^{-1}$ and 3 to $15 \mathrm{mBq} \cdot \mathrm{kg}^{-1} \cdot \mathrm{h}^{-1}$ respectively. The lowest values are identified for gypsum, while the highest are attributed to granite. All of the obtained results of these indices respect the permissible limits except for
\end{abstract}


the $R a_{e q}$ in some granite samples, the ELCR index in all samples except gypsum and the radon volumic activity in some gray cement samples, ceramic and granite. As a result, the different types of building materials analyzed in our work do not present a health risk to the public and can be used in various construction activities, with the exception of a few samples of red brick, gray cement, ceramic and granite. The choice of the use of red brick, gray cement and ceramic should be monitored and adapted according to the criteria of the limitation of the doses whereas the use of the granite must be moderate in order to limit over time the health risk which increases with the duration of exposure of humans to these building materials.

\section{Keywords}

Building Materials, Natural Radioactivity, Radionuclide, Radon Exhalation Rate, Radium Equivalent, Annual Effective Dose

\section{Introduction}

Since 1970, indoor air quality has become a major preoccupation for public health, due in part to the time we spend indoors (on average 87\%) [1] and the high diversity of the airborne contaminants found therein, biological, chemical and physical [2]. Building materials represent a continuous source of natural radiation because it is produced from rocks and soils that contain radioactivity at varying levels depending on their origins [3] [4]. Radioactive exposure to building materials can be divided into internal and external exposure. This latter is due to gamma radiation from the different radionuclides of the three radioactive decay chains $\left({ }^{238} \mathrm{U},{ }^{235} \mathrm{U},{ }^{232} \mathrm{Th}\right)$ and ${ }^{40} \mathrm{~K}$. Internal exposure is due to the inhalation of radon and its progeny. ${ }^{222} \mathrm{Rn}$ is now considered the main source of human exposure to natural radiation [5]. It is a naturally occurring radioactive gas from the disintegration of ${ }^{226} \mathrm{Ra}$, itself part of the ${ }^{238} \mathrm{U}$ disintegration chain. When disintegrating, radon emits alpha particles and generates solid progeny, which are also radioactive (polonium, bismuth, lead, etc.). These descendants continue to disintegrate and emit radiation, in particular of the $\alpha$ and $\beta$ type. Once inhaled, it dissipates their energies into the surrounding lung tissue, thereby damaging the lung cells, and altering their atomic structure. In 1987, the International Agency for Research on Cancer (IARC) of the World Health Organization (WHO) recognized radon as a pulmonary carcinogen for humans [5].

In Morocco, the building materials industry is currently experiencing significant growth. A growing demand means the creation or expansion of several production units (cement works, brickworks, etc.). In recent years, the building industry uses a raw material, large quantities of waste with a technologically enhanced natural radioactivity (coal ash, phosphogypses, etc.) [6] [7] [8]. The use of these materials in building materials has economic advantages but may affect the doses received by humans inside buildings as has been demonstrated in var- 
ious studies [9] [10] [11]. Hence, the knowledge of the natural radioactivity in buildings materials from the three radioactive decay chains $\left({ }^{238} \mathrm{U},{ }^{235} \mathrm{U},{ }^{232} \mathrm{Th}\right)$ and ${ }^{40} \mathrm{~K}$, is necessary and important for the assessment of the radiological impact on the public and the environment. To evaluate the radiological impact of these materials on the population and the environment, and through these specific activities, we calculated several radiological risk indices, namely radium equivalent $\left(R a_{e q}\right)$, internal $\left(H_{i n}\right)$ and external $\left(H_{e x}\right)$ hazard indices, total annual effective dose $\left(\dot{E}_{t o t}\right)$ as well as the excess lifetime cancer risk (ELCR).

\section{Materials and Methods}

\subsection{Sample Preparation}

The building materials samples to be analyzed are collected from large and important commercial suppliers in Morocco. As regards sand, samples are taken from seven different quarries in the Doukkala region. Before any analysis and to obtain homogeneous samples, these building materials are dried in an oven at $40^{\circ} \mathrm{C}$ for 24 hours and then ground and sieved through a $100 \mu \mathrm{m}$ mesh screen. The screened samples are packaged in radon-tight containers for at least 4 weeks to establish the secular equilibrium corresponding to seven half-lives of ${ }^{222} \mathrm{Rn}$.

\subsection{Spectroscopic Analysis}

The measurement of the natural radioactivity in the prepared samples is carried out by gamma ray spectrometer using the Broad Energy Germanium detector (BEGe) at Pluridisciplinary Institute Hubert Curien in Strasbourg, France. It is a planar type Hyper-Pure Germanium HPGe detector associated with a set of electronic modules for shaping the pulses, amplifying and storing the pulses delivered during the passage of the gamma rays through the detector. Its energy measurement range is 30 to $3000 \mathrm{keV}$ with a resolution of $0.633 \mathrm{keV}$ to $122 \mathrm{keV}$ and from $1.934 \mathrm{keV}$ to $1332 \mathrm{keV}$ [12].

As regards the energy and efficiency calibration of the BEGe detector, a multi-energy certified standard is analyzed under the same conditions and geometry as the samples studied. This standard contains several $\gamma$-emitting radionuclides such as ${ }^{241} \mathrm{Am}(60 \mathrm{keV}),{ }^{109} \mathrm{Cd}(88 \mathrm{keV}),{ }^{57} \mathrm{Co}(122,136 \mathrm{keV}),{ }^{139} \mathrm{Ce}$ (165 keV), ${ }^{51} \mathrm{Cr}(320 \mathrm{keV}),{ }^{113} \mathrm{Sn}(391 \mathrm{keV}),{ }^{85} \mathrm{Sr}(514 \mathrm{keV}),{ }^{137} \mathrm{Cs}(661 \mathrm{keV}),{ }^{88} \mathrm{Y}$ $(898,1836 \mathrm{keV})$ and ${ }^{60} \mathrm{Co}(1173,1332 \mathrm{keV})$. Samples of building materials are packaged in SG50 geometry and counted for 172.800 seconds. The treatment of the amplitude spectra is carried out using automatic analysis software Genie 2000 [12] allowing to give directly the mass activity of each radioelement present in the sample.

The volumetric activities and the exhalation rate in terms of area and mass of the radon in the prepared samples are carried out using the alpha dosimetry. For this purpose, several pieces of $2 \times 2 \mathrm{~cm}^{2}$ of Solid State Nuclear Track Detector (SSNTD) LR115 type 2 non strippable, Kodak brand $12 \mu \mathrm{m}$ thick, are exposed in sealed cylindrical "cans" of $5.5 \mathrm{~cm}$ diameter and $9.5 \mathrm{~cm}$ height by $50 \mathrm{~g}$ of each 
sample of building materials. After two months of irradiation, the LR115 are chemically treated in a $2.5 \mathrm{~N}$ sodium hydroxide solution during $100 \mathrm{~min}$ at a temperature of $60^{\circ} \mathrm{C}$. The developed films are read using an optical microscope. The density of traces per unit area and per unit time in LR115 and the volume activity of radon $A_{V}^{R n}$ are determined according to [13].

\section{Results and Discussions}

\subsection{Specific Activities}

The specific activities of the radionuclides ${ }^{226} \mathrm{Ra},{ }^{232} \mathrm{Th}$ and ${ }^{40} \mathrm{~K}$ are calculated by gamma spectrometry, after establishment of the secular equilibrium, in the various samples of building materials using the following ratios of energies:

- ${ }^{214} \mathrm{~Pb}(295 \mathrm{keV}$ and $352 \mathrm{keV})$ and ${ }^{214} \mathrm{Bi}(609 \mathrm{keV}, 1120 \mathrm{keV}$ and $1764 \mathrm{keV})$ for ${ }^{226} \mathrm{Ra}$;

- ${ }^{228} \mathrm{Ac}(911 \mathrm{keV}$ and $969 \mathrm{keV})$ and ${ }^{212} \mathrm{~Pb}(239 \mathrm{keV})$ for ${ }^{232} \mathrm{Th}$;

- ${ }^{40} \mathrm{~K}(1461 \mathrm{keV})$ from the emission intensity line $10.55 \%$.

Figure 1 shows the minimum, the maximum and the average specific activities of ${ }^{226} \mathrm{Ra}$, ${ }^{232} \mathrm{Th}$ and ${ }^{40} \mathrm{~K}$ radionuclides measured in the different types of
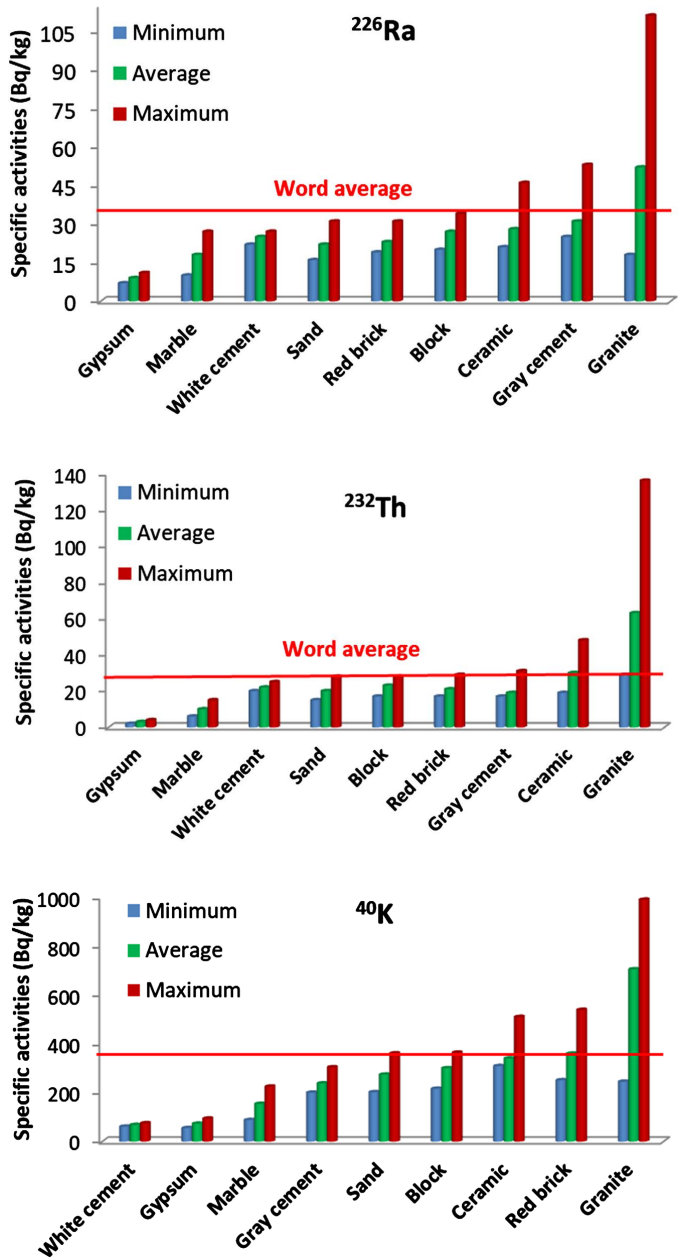

Figure 1. Specific activities of different radionuclides in Moroccan building materials. 
building materials. It can be seen that the contribution of the activity of the ${ }^{40} \mathrm{~K}$ is much greater than that contributed by the ${ }^{238} \mathrm{U}$ and the ${ }^{232} \mathrm{Th}$. It should also be noted that the activity of ${ }^{232} \mathrm{Th}$ in each sample is less than that of ${ }^{226} \mathrm{Ra}$ except for the red brick, ceramic and granite samples.

From these values, it results that the low average specific activities are recorded in the gypsum for the radionuclides ${ }^{226} \mathrm{Ra}$ and ${ }^{232} \mathrm{Th}$, and in the white cement for the ${ }^{40} \mathrm{~K}$ with average activities of the order of $9 \mathrm{~Bq} / \mathrm{kg}, 3 \mathrm{~Bq} / \mathrm{kg}$ and $68 \mathrm{~Bq} / \mathrm{kg}$ respectively. The highest average specific activities for the ${ }^{226} \mathrm{Ra},{ }^{232} \mathrm{Th}$ and ${ }^{40} \mathrm{~K}$ radionuclides are recorded in the granite and are respectively of the order of $52 \mathrm{~Bq} / \mathrm{kg}, 63 \mathrm{~Bq} / \mathrm{kg}$ and $705 \mathrm{~Bq} / \mathrm{kg}$. All the specific activities of the measured ${ }^{226} \mathrm{Ra},{ }^{232} \mathrm{Th}$ and ${ }^{40} \mathrm{~K}$ are within the permissible limits of $35 \mathrm{~Bq} / \mathrm{kg}, 30 \mathrm{~Bq} / \mathrm{kg}$ and $370 \mathrm{~Bq} / \mathrm{kg}$ [4], respectively, with the exception of a few samples of red brick, gray cement, ceramic and granite. Therefore, the choice of materials for building constructions should be monitored and adapted according to the criteria of the limitation of doses.

In Table 1, and for comparison with our results, the specific activities of natural radionuclides are grouped together in samples of building materials in Morocco and some other countries. Overall, the specific activities obtained in this study are comparable to those found in other countries, with the exception of a few activities that are remarkably higher than ours.

\subsection{Radium Equivalent}

Due to the non-uniform distribution of natural radionuclides in building material samples, the radiological index radium equivalent $R a_{e q}$ is generally represented as the sum of the specific activities of ${ }^{226} \mathrm{Ra},{ }^{232} \mathrm{Th}$ and ${ }^{40} \mathrm{~K}$ based on the assumption that $10 \mathrm{~Bq} / \mathrm{Kg}$ of ${ }^{226} \mathrm{Ra}, 7 \mathrm{~Bq} / \mathrm{kg}$ of ${ }^{232} \mathrm{Th}$ and $130 \mathrm{~Bq} / \mathrm{kg}$ of ${ }^{40} \mathrm{~K}$ would produce the same dose rate of gamma radiation. This is the most widely used index for radiological risk assessment. It is calculated using the following equation [5] [28]:

$$
R a_{e q}=A_{226 \mathrm{Ra}}+1.43 A_{232 \mathrm{Th}}+0.077 A_{40 \mathrm{~K}}
$$

where $A_{226 \mathrm{Ra}}, A_{232 \mathrm{Th}}$ and $A_{40 \mathrm{~K}}$ are the specific activities in $(\mathrm{Bq} / \mathrm{kg})$ of ${ }^{226} \mathrm{Ra}$, ${ }^{232} \mathrm{Th}$ and ${ }^{40} \mathrm{~K}$ in the samples analyzed.

In Table 2, the mean values of the radium equivalent $R a_{e q}$ varying from 19 to $196 \mathrm{~Bq} / \mathrm{kg}$, which are still below the permissible limit of $370 \mathrm{~Bq} / \mathrm{kg}$ [5], are grouped together for the samples analyzed. We note that the lowest value is found in the gypsum, while the highest is in the granite.

From these results, we can consider that these building materials do not present a significant radiological hazard to the population and can be used in various construction activities. However, it should be noted that the $R a_{e q}$ values vary considerably in the same type of building materials and may in some cases exceed the permissible limit. This is the case of granite where the maximum value of the equivalent radium $R a_{e q}$ is of the order of $382 \mathrm{~Bq} / \mathrm{kg}$. The use of the latter in construction activities must be moderate. 
Table 1. Comparison between the specific activities of building materials in a few countries.

\begin{tabular}{|c|c|c|c|c|c|}
\hline \multirow{2}{*}{ Samples } & \multirow{2}{*}{ Country } & \multicolumn{3}{|c|}{ Specific activities $(\mathrm{Bq} / \mathrm{kg})$} & \multirow{2}{*}{ References } \\
\hline & & ${ }^{226} \mathrm{Ra}$ & ${ }^{232} \mathrm{Th}$ & ${ }^{40} \mathrm{~K}$ & \\
\hline \multirow{5}{*}{$\begin{array}{c}\text { Gray } \\
\text { Cement }\end{array}$} & European Union & 45 & 31 & 216 & [14] \\
\hline & China & $21.7 \pm 1.92$ & $22 \pm 0.89$ & $181 \pm 3.75$ & [15] \\
\hline & Turkey & $39.9 \pm 18.0$ & $26.4 \pm 9.8$ & $316.5 \pm 88.1$ & {$[16]$} \\
\hline & South Korea & $34.5 \pm 1.7$ & $19.4 \pm 1.5$ & $241 \pm 6.7$ & [17] \\
\hline & Morocco & $31 \pm 5$ & $19 \pm 3$ & $238 \pm 29$ & Present Work \\
\hline \multirow{6}{*}{$\begin{array}{l}\text { White } \\
\text { Cement }\end{array}$} & Egypt & $17.45 \pm 2.33$ & $8.44 \pm 1.49$ & $4.09 \pm 4.72$ & {$[18]$} \\
\hline & Turkey & $32.8 \pm 5.1$ & $16.3 \pm 7.6$ & $99.2 \pm 31.8$ & [16] \\
\hline & Qatar & $18.9 \pm 0.5$ & $4.9 \pm 0.5$ & $62.9 \pm 22.6$ & [19] \\
\hline & Serbia & $18 \pm 3$ & $12 \pm 5$ & $55 \pm 37$ & [20] \\
\hline & Iraq & $49.577 \pm 0.865$ & $16.74 \pm 2.28$ & $32.6 \pm 4.31$ & [21] \\
\hline & Morocco & $25 \pm 4$ & $22 \pm 3$ & $68 \pm 8$ & Present Work \\
\hline \multirow{4}{*}{ Gypsum } & Saudi Arabia & $33.28 \pm 4.7$ & $47.2 \pm 2.8$ & $88 \pm 4.4$ & [22] \\
\hline & Italy & $6 \pm 5$ & $2 \pm 2$ & $32 \pm 43$ & [23] \\
\hline & Iran & $8.1 \pm 0.1$ & $2.2 \pm 0.1$ & $116 \pm 11$ & [24] \\
\hline & Morocco & $9 \pm 1$ & $3 \pm 1$ & $73 \pm 9$ & Present Work \\
\hline \multirow{4}{*}{ Red brick } & Iran & $37.0 \pm 1.5$ & $12.2 \pm 0.7$ & $851 \pm 15$ & [24] \\
\hline & Albania & $33.4 \pm 6.4$ & $42.2 \pm 7.6$ & $644.1 \pm 64.2$ & [25] \\
\hline & Egypt & $23.06 \pm 2.60$ & $23.11 \pm 2.99$ & $447.84 \pm 10.16$ & [18] \\
\hline & Morocco & $23 \pm 4$ & $21 \pm 3$ & $360 \pm 41$ & Present Work \\
\hline \multirow{3}{*}{ Block } & Egypt & $288.5 \pm 17.49$ & $77.77 \pm 15.61$ & $909.5 \pm 59.73$ & [18] \\
\hline & Iran & $20.7 \pm 1.1$ & $3.0 \pm 0.4$ & $436 \pm 14$ & [24] \\
\hline & Morocco & $27 \pm 3$ & $23 \pm 3$ & $300 \pm 37$ & Present Work \\
\hline \multirow{4}{*}{ Ceramic } & Egypt & $51.12 \pm 2.74$ & $40.52 \pm 2.54$ & $682.6 \pm 10.13$ & [18] \\
\hline & Turkey & $33.1 \pm 2.5$ & $49.5 \pm 3.3$ & $459.1 \pm 51.3$ & {$[26]$} \\
\hline & Syria & $65.878 \pm 1.0$ & $28.16 \pm 3.0$ & $401 \pm 14.67$ & [21] \\
\hline & Morocco & $28 \pm 5$ & $30 \pm 5$ & $340 \pm 42$ & Present Work \\
\hline \multirow{3}{*}{ Marble } & Saudi Arabia & $12.7 \pm 3.4$ & $13.2 \pm 1.4$ & $64 \pm 3$ & [22] \\
\hline & Algeria & $23 \pm 2$ & $18 \pm 2$ & $310 \pm 3$ & [27] \\
\hline & Morocco & $18 \pm 2$ & $10 \pm 1$ & $154 \pm 19$ & Present Work \\
\hline \multirow{3}{*}{ Granite } & Saudi Arabia & $23 \pm 1.4$ & $30.0 \pm 0.4$ & $340 \pm 6.7$ & {$[22]$} \\
\hline & Turkey & $67.5 \pm 47.6$ & $77.4 \pm 53.0$ & $915.3 \pm 361.2$ & [16] \\
\hline & Morocco & $52 \pm 6$ & $63 \pm 8$ & $705 \pm 84$ & Present Work \\
\hline \multirow{4}{*}{ Sand } & Turkey & $38.8 \pm 10.0$ & $29.5 \pm 11.3$ & $471.4 \pm 101.2$ & [26] \\
\hline & Qatar & $13.2 \pm 0.3$ & $3.34 \pm 0.05$ & $225.5 \pm 6.1$ & [19] \\
\hline & Pakistan & $21.5 \pm 0.5$ & $31.9 \pm 0.5$ & $519.6 \pm 6.0$ & [28] \\
\hline & Morocco & $22 \pm 3$ & $20 \pm 3$ & $274 \pm 47$ & Present Work \\
\hline
\end{tabular}


Table 2. Average values of radium equivalent, hazard indices, absorbed dose rate, annual effective dose and the excess lifetime cancer risk in the samples of building materials analyzed.

\begin{tabular}{ccccccccc}
\hline Samples & $\begin{array}{c}R a_{e q} \\
(\mathrm{~Bq} / \mathrm{kg})\end{array}$ & $H_{\text {in }}$ & $H_{e x}$ & $\begin{array}{c}\dot{D} \\
(\mathrm{nGy} / \mathrm{h})\end{array}$ & $\begin{array}{c}\dot{E}_{\text {in }} \\
(\mathrm{mSv} / \mathrm{y})\end{array}$ & $\begin{array}{c}\dot{E}_{\text {ex }} \\
(\mathrm{mSv} / \mathrm{y})\end{array}$ & $\begin{array}{c}\dot{E}_{\text {tot }} \\
(\mathrm{mSv} / \mathrm{y})\end{array}$ & $\begin{array}{c}\text { ELCR } \\
\left(\times 10^{-3}\right)\end{array}$ \\
\hline Graycement & $77 \pm 7$ & $0.29 \pm 0.05$ & $0.21 \pm 0.04$ & $36 \pm 2$ & $0.18 \pm 0.04$ & $0.04 \pm 0.01$ & $0.18 \pm 0.04$ & $0.77 \pm 0.06$ \\
Gypsum & $19 \pm 2$ & $0.08 \pm 0.02$ & $0.05 \pm 0.02$ & $9 \pm 1$ & $0.04 \pm 0.01$ & $0.01 \pm 0.01$ & $0.04 \pm 0.01$ & $0.19 \pm 0.01$ \\
Whitecement & $62 \pm 4$ & $0.23 \pm 0.04$ & $0.17 \pm 0.03$ & $28 \pm 1$ & $0.14 \pm 0.03$ & $0.03 \pm 0.01$ & $0.14 \pm 0.03$ & $0.60 \pm 0.05$ \\
Red brick & $82 \pm 12$ & $0.28 \pm 0.04$ & $0.22 \pm 0.04$ & $39 \pm 4$ & $0.19 \pm 0.04$ & $0.05 \pm 0.01$ & $0.19 \pm 0.04$ & $0.83 \pm 0.07$ \\
Block & $82 \pm 11$ & $0.30 \pm 0.05$ & $0.22 \pm 0.04$ & $39 \pm 3$ & $0.19 \pm 0.04$ & $0.05 \pm 0.01$ & $0.19 \pm 0.04$ & $0.83 \pm 0.07$ \\
Ceramic & $97 \pm 14$ & $0.34 \pm 0.05$ & $0.26 \pm 0.05$ & $45 \pm 5$ & $0.22 \pm 0.05$ & $0.06 \pm 0.02$ & $0.22 \pm 0.05$ & $0.97 \pm 0.09$ \\
Marble & $45 \pm 4$ & $0.17 \pm 0.03$ & $0.12 \pm 0.02$ & $21 \pm 1$ & $0.10 \pm 0.03$ & $0.03 \pm 0.01$ & $0.10 \pm 0.03$ & $0.45 \pm 0.04$ \\
Granite & $196 \pm 17$ & $0.67 \pm 0.06$ & $0.53 \pm 0.05$ & $91 \pm 7$ & $0.45 \pm 0.08$ & $0.11 \pm 0.03$ & $0.45 \pm 0.08$ & $1.96 \pm 0.10$ \\
Sand & $72 \pm 8$ & $0.26 \pm 0.04$ & $0.20 \pm 0.04$ & $34 \pm 3$ & $0.17 \pm 0.04$ & $0.04 \pm 0.01$ & $0.17 \pm 0.04$ & $0.73 \pm 0.07$ \\
\hline
\end{tabular}

\subsection{Internal and External Hazard Indices}

The calculation of the total activity of radionuclides in building materials alone does not make it possible to assess the radiological risks of gamma radiation. Other risk indices are also taken into account and are defined by a model taking into account the maximum activity of $R a_{e q}(370 \mathrm{~Bq} / \mathrm{kg})$. The external hazard index $H_{e x}$ is defined by the following equation [5] [28]:

$$
H_{e x}=\frac{A_{226 \mathrm{Ra}}}{370}+\frac{A_{232 \mathrm{Th}}}{259}+\frac{A_{40 \mathrm{~K}}}{4810}
$$

In addition to this external hazard, the respiratory organs are threatened because of the decay of ${ }^{226} \mathrm{Ra}$ into ${ }^{222} \mathrm{Rn}$ and its descendants. To account for this threat, the maximum permissible activity for ${ }^{226} \mathrm{Ra}$ is therefore reduced by half (185 Bq/kg). This internal hazard $H_{\text {in }}$ is quantified by the following relation [5] [28]:

$$
H_{\text {in }}=\frac{A_{226 \mathrm{Ra}}}{185}+\frac{A_{232 \mathrm{Th}}}{259}+\frac{A_{40 \mathrm{~K}}}{4810}
$$

Table 2 gives the internal and external hazard indices of the samples of the building materials studied. The values of the internal hazard index according to the materials vary between 0.08 and 0.67 while for the external hazard index they are between 0.05 and 0.53 . The values are maximum for granite and minimum for gypsum. None of these values exceeds the unit, the maximum value of the internal $\left(H_{i n}\right)$ and external $\left(H_{e x}\right)$ hazard indices allowed.

\subsection{Absorbed Dose Rate and Annual Effective Dose}

The absorbed dose rate $\dot{D}$ (nGy/h) due to the specific activity of natural radionuclides from building materials in air at $1 \mathrm{~m}$ height is defined by the following equation [5]:

$$
\dot{D}(\mathrm{nGy} / \mathrm{h})=0.462 A_{226 \mathrm{Ra}}+0.604 A_{232 \mathrm{Th}}+0.0417 A_{40 \mathrm{~K}}
$$


Table 2 summarizes the results of the absorbed dose rates in air for the analyzed building materials. We note that the highest value is attributed to granite (91 nGy/h) while the lowest value is gypsum ( $9 \mathrm{nGy} / \mathrm{h})$. These values of absorbed dose rates are below the permissible limit (55 $\mathrm{nGy} / \mathrm{h}$ ) [5] with the exception of the granite sample.

To estimate the annual effective dose received by the population, we take into account the coefficient of conversion of dose rate absorbed in air in effective dose (0.7 Sv/Gy) and external occupancy factor (0.2) [5]. The annual effective doses are determined as follows [5]:

$$
\begin{aligned}
& \dot{E}_{e x}(\mathrm{mSv} / \mathrm{y})=\dot{D}(\mathrm{nGy} / \mathrm{h}) \times 8760(\mathrm{~h}) \times 0.2 \times 0.7(\mathrm{~Sv} / \mathrm{Gy}) 10^{-6} \\
& \dot{E}_{\text {in }}(\mathrm{mSv} / \mathrm{y})=\dot{D}(\mathrm{nGy} / \mathrm{h}) \times 8760(\mathrm{~h}) \times 0.8 \times 0.7(\mathrm{~Sv} / \mathrm{Gy}) 10^{-6}
\end{aligned}
$$

The results of the annual external $\left(\dot{E}_{e x}\right)$, internal $\left(\dot{E}_{\text {in }}\right)$ and total $\left(\dot{E}_{\text {tot }}\right)$ effective doses for the samples of building materials studied are given in Table 2 . It is found that the total value for each sample is less than the annual effective dose limit set at $1 \mathrm{mSv} / \mathrm{y}$ [5]. Therefore, we consider that these building materials do not present a radiological risk to the population and can be used in the construction of buildings.

\subsection{Excess Lifetime Cancer Risk}

The Excess Lifetime Cancer Risk (ELCR) treats the probability of developing cancer during the life of a human being at a certain level of exposure. The ELCR is calculated using the following equation [29]:

$$
\mathrm{ELCR}=\dot{E}_{\text {tot }} \times \mathrm{DL} \times \mathrm{RF}
$$

Or:

$\dot{E}_{\text {tot }}$ is the total annual effective dose ( $\mu$ Sv/year);

DL (Duration of Life) is the average life span of a human being (70 years);

$\mathrm{RF}$ is the Risk Factor fatal by cancer $\left(\mathrm{Sv}^{-1}\right)$. For stochastic effects, the International Commission on Radiological Protection (ICRP) estimates the value of this factor to be 0.05 for the public [30].

In Table 2, ELCR values range from $0.19 \times 10^{-3}$ to $1.96 \times 10^{-3}$ where the lowest value is found in the gypsum, while the highest is in the granite. The ELCR value at the granite sample far exceeds the permissible limit of $0.29 \times 10^{-3}$ [29]. As a result, the risk of cancer increases with increasing exposure to these materials.

\subsection{Volume Activities and Radon Exhalation Rates}

After calculating the density of traces per unit area and per unit time in the LR115, the volume activities of the radon $A_{V}^{R n}$ are calculated using the detection efficiency equal to $0.0258\left(\right.$ traces $\left.\cdot \mathrm{cm}^{-2} \cdot \mathrm{j}^{-1}\right) /\left(\mathrm{Bq} \cdot \mathrm{m}^{-3}\right)$ [31]. The exhalation rate in terms of area $\left(E_{S}\right.$ in Bq. $\left.\mathrm{m}^{-2} \cdot \mathrm{h}^{-1}\right)$ and mass $\left(E_{M}\right.$ in $\left.\mathrm{Bq} \cdot \mathrm{kg}^{-1} \cdot \mathrm{h}^{-1}\right)$ of ${ }^{222} \mathrm{Rn}$ are determined by the following equation [32] [33]: 


$$
\begin{gathered}
E_{S}=\frac{A_{V}^{R n} V \lambda_{R n}}{S_{e}\left[t+\left(\frac{1}{\lambda_{R n}}\right)\left(\mathrm{e}^{-\lambda_{R n} t}-1\right)\right]} \\
E_{M}=\frac{A_{V}^{R n} V \lambda_{R n}}{M\left[t+\left(\frac{1}{\lambda_{R n}}\right)\left(\mathrm{e}^{-\lambda_{R n} t}-1\right)\right]}
\end{gathered}
$$

With $A_{V}^{R n}$ is the volume activity of radon $\left(\mathrm{Bq} \cdot \mathrm{m}^{-3} \cdot \mathrm{h}\right) ; V$ is the volume of the enclosure $\left(\mathrm{m}^{3}\right) ; \lambda_{R n}$ is the ${ }^{222} \mathrm{Rn}$ decay constant $\left(\mathrm{h}^{-1}\right) ; S_{e}$ is the area of the sample $\left(\mathrm{m}^{2}\right) ; M$ is the mass of the sample in $\mathrm{kg}$ and $\mathrm{t}$ is the exposure time (h).

We present in Table 3 the average values of the volumetric activity and exhalation rate in terms of area and mass of radon measured in the samples of the building materials analyzed. These values vary respectively from (72 to $\left.350 \mathrm{~Bq} / \mathrm{m}^{3}\right)$, ( 56 to $273 \mathrm{mBq} \cdot \mathrm{m}^{-2} \cdot \mathrm{h}^{-1}$ ) and ( 3 to $15 \mathrm{mBq} \cdot \mathrm{kg}^{-1} \cdot \mathrm{h}^{-1}$ ) where the lowest values are identified in the gypsum, while the highest values are in the granite. All volumic activity values for radon are in the range of 100 to $300 \mathrm{~Bq} / \mathrm{m}^{3}$ recommended by ICRP [34] with the exception of some samples of gray cement (191 to $\left.366 \mathrm{~Bq} / \mathrm{m}^{3}\right)$, ceramic (159 to $322 \mathrm{~Bq} / \mathrm{m}^{3}$ ) and granite $\left(132\right.$ to $\left.610 \mathrm{~Bq} / \mathrm{m}^{3}\right)$.

In Table 4, for comparison with our results, the volumetric activities and exhalation rates in terms of area and mass of radon in building materials samples in Morocco and some other countries. Overall, the obtained results in this study are comparable to those found in other countries, with the exception of a few values that are remarkably higher than ours.

A positive correlation is found between the specific activities of ${ }^{226} \mathrm{Ra}$ on the one hand, it is determined by high resolution gamma spectrometry and the exhalation rates of ${ }^{222} \mathrm{Rn}$ calculated with the alpha dosimetry based on the use of LR115 on the other hand. This correlation is illustrated in Figure 2 with a correlation coefficient in the order of 0.96 .

Table 3. Volume activity and exhalation rate of radon in different samples of Moroccan building materials.

\begin{tabular}{cccccccc}
\hline Samples & & \multicolumn{2}{c}{$A_{V}^{R n}\left(\mathrm{~Bq} / \mathrm{m}^{3}\right)$} & \multicolumn{2}{c}{$E_{S}\left(\mathrm{mBq} \cdot \mathrm{m}^{-2} \cdot \mathrm{h}^{-1}\right)$} & \multicolumn{2}{c}{$E_{M}\left(\mathrm{mBq} \cdot \mathrm{kg}^{-1} \cdot \mathrm{h}^{-1}\right)$} \\
\hline Type & Nr. & Range & Average & Range & Average & Range & Average \\
\hline Gray cement & 7 & $191-366$ & $248 \pm 26$ & $149-286$ & $194 \pm 21$ & $8-15$ & $10 \pm 2$ \\
Gypsum & 5 & $54-92$ & $72 \pm 7$ & $42-72$ & $56 \pm 4$ & $2-4$ & $3 \pm 1$ \\
White cement & 5 & $184-198$ & $191 \pm 19$ & $144-155$ & $149 \pm 15$ & $7-8$ & $7 \pm 1$ \\
Red brick & 5 & $130-192$ & $159 \pm 16$ & $101-150$ & $124 \pm 13$ & $5-8$ & $7 \pm 1$ \\
Block & 5 & $140-211$ & $176 \pm 19$ & $109-165$ & $137 \pm 19$ & $6-9$ & $7 \pm 1$ \\
Ceramic & 6 & $159-322$ & $226 \pm 22$ & $124-251$ & $176 \pm 18$ & $7-13$ & $10 \pm 2$ \\
Marble & 5 & $69-220$ & $151 \pm 16$ & $54-172$ & $118 \pm 12$ & $3-9$ & $6 \pm 1$ \\
Granite & 5 & $132-610$ & $350 \pm 34$ & $103-476$ & $273 \pm 26$ & $5-25$ & $15 \pm 3$ \\
Sand & 7 & $140-275$ & $190 \pm 20$ & $109-215$ & $148 \pm 16$ & $6-11$ & $8 \pm 1$ \\
\hline
\end{tabular}




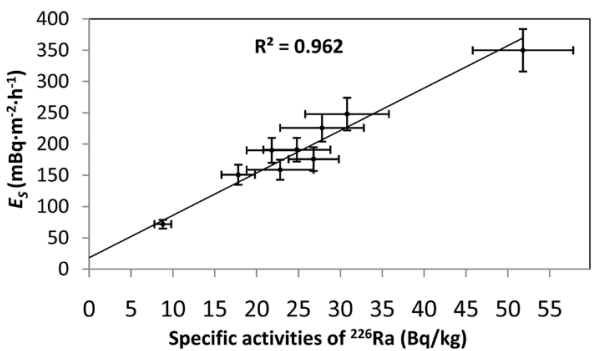

Figure 2. Correlation between the specific activities of ${ }^{226} \mathrm{Ra}$ and the exhalation rate of ${ }^{222} \mathrm{Rnin}$ building materials samples.

Table 4. Comparison between the Radon volume activities and the exhalation rates of radon in building materials in a few countries.

\begin{tabular}{|c|c|c|c|c|c|}
\hline Samples & Country & $\begin{array}{c}A_{V}^{R n} \\
\left(\mathrm{~Bq} / \mathrm{m}^{3}\right)\end{array}$ & $\begin{array}{c}E_{S} \\
\left(\mathrm{mBq} \cdot \mathrm{m}^{-2} \cdot \mathrm{h}^{-1}\right)\end{array}$ & $\begin{array}{c}E_{M} \\
\left(\mathrm{mBq} \cdot \mathrm{Kg}^{-1} \cdot \mathrm{h}^{-1}\right)\end{array}$ & References \\
\hline \multirow{3}{*}{ Gray cement } & India & 307 & 244 & 11.2 & [35] \\
\hline & Jordan & 177 & 90 & 6 & {$[36]$} \\
\hline & Morocco & 248 & 194 & 10 & Present Work \\
\hline \multirow{3}{*}{$\begin{array}{l}\text { Cement } \\
\text { White }\end{array}$} & Palestine & 102 & 63 & 6.4 & [37] \\
\hline & India & 365 & 288 & 13.3 & [35] \\
\hline & Morocco & 191 & 149 & 7 & Present Work \\
\hline \multirow{3}{*}{ Gypsum } & Saudi Arabia & 157.5 & 145.7 & 4.6 & [38] \\
\hline & Algeria & 42 & 36 & - & [39] \\
\hline & Morocco & 72 & 56 & 3 & Present Work \\
\hline \multirow{2}{*}{$\begin{array}{l}\text { Brick } \\
\text { red }\end{array}$} & Algeria & 166 & 101 & - & [39] \\
\hline & Morocco & 159 & 124 & 7 & Present Work \\
\hline \multirow{3}{*}{ Block } & India & 235 & 241 & - & [40] \\
\hline & Jordan & 160 & 82 & 6 & [36] \\
\hline & Morocco & 176 & 137 & 7 & Present Work \\
\hline \multirow{3}{*}{ Ceramic } & Algeria & 75 & 65 & - & [39] \\
\hline & Palestine & 132 & 75 & 3.2 & [37] \\
\hline & Morocco & 226 & 176 & 10 & Present Work \\
\hline \multirow{4}{*}{ Marble } & Algeria & 56 & 48 & - & [39] \\
\hline & Libya & 264.6 & 212.7 & 9.8 & {$[41]$} \\
\hline & Saudi Arabia & 76.4 & 72.3 & - & [38] \\
\hline & Morocco & 151 & 118 & 6 & Present Work \\
\hline \multirow{2}{*}{ Granite } & Palestine & 246 & 146 & 7.2 & [37] \\
\hline & Morocco & 350 & 273 & 15 & Present Work \\
\hline \multirow{3}{*}{ Sand } & Palestine & 84 & 48 & 2.4 & [37] \\
\hline & Jordan & 267 & 149 & 14 & [36] \\
\hline & Morocco & 190 & 148 & 8 & Present Work \\
\hline
\end{tabular}




\section{Conclusion}

In this present work, we used gamma spectrometry to determine natural radioactivity in 50 samples of building materials commonly used in Morocco. The specific activities of the ${ }^{226} \mathrm{Ra},{ }^{232} \mathrm{Th}$ and ${ }^{40} \mathrm{~K}$ radionuclides measured in these samples vary from 9 to $52 \mathrm{~Bq} / \mathrm{kg}$, from 3 to $63 \mathrm{~Bq} / \mathrm{kg}$ and from 68 to $705 \mathrm{~Bq} / \mathrm{kg}$ respectively. These activities of the studied samples are within the permissible limits with the exception of a few samples of red brick, gray cement, ceramic and granite. To evaluate the radiological impact of these building materials on the population, the environment and through these specific activities, we calculated several radiological risk indices, namely radium equivalent $\left(R a_{e q}\right)$, internal $\left(H_{i n}\right)$ and external $\left(H_{e x}\right)$ hazard indices, the absorbed dose rate $(\dot{D})$, the total annual effective dose $\left(\dot{E}_{t o t}\right)$, the excess lifetime cancer risk (ELCR), the volume activities $\left(A_{V}^{R n}\right)$ and the exhalation rate in terms of area $\left(E_{S}\right)$ and mass $\left(E_{M}\right)$. It follows that the values of these indices vary from 19 to $196 \mathrm{~Bq} / \mathrm{kg}, 0.07$ to $0.67,0.05$ to $0.53,9$ to $91 \mathrm{nGy} / \mathrm{h}, 0.05$ to $0.56 \mathrm{mSv} / \mathrm{y}, 0.19 \times 10^{-3}$ to $1.96 \times 10^{-3}, 72$ to $305 \mathrm{~Bq} / \mathrm{m}^{3}$, 56 to $273 \mathrm{mBq} \cdot \mathrm{m}^{-2} \cdot \mathrm{h}^{-1}$ and 3 to $15 \mathrm{mBq} \cdot \mathrm{kg}^{-1} \cdot \mathrm{h}^{-1}$ respectively. The lowest values are identified for gypsum, while the highest are attributed to granite. All of the obtained results of these indices respect the permissible limits except for the $R a_{e q}$ in some granite samples, the ELCR index in all samples except gypsum and the radon volumic activity in some gray cement samples, ceramic and granite. Consequently, the different types of building materials analyzed in this work do not present any significant health risks to the public and can be used in various construction activities with the exception of a few samples of red brick, gray cement, ceramic and granite. The choice of the use of red brick, gray cement and ceramic should be monitored and adapted according to the criteria of the limitation of the doses whereas the use of the granite must be moderate in order to limit over time the health risk which increases with the duration of exposure of humans to these building materials.

\section{Conflicts of Interest}

The authors declare no conflicts of interest regarding the publication of this paper.

\section{References}

[1] Klepeis, N.E., Nelson, W.C., Ott, W.R., Robinson, J.P., Tsang, A.M., Switzer, P., Behar, J.V., Hern, S.C. and Engelmann, W.H. (2001) The National Human Activity Pattern Survey (NHAPS): A Resource for Assessing Exposure to Environmental Pollutants. Journal of Exposure Analysis and Environmental Epidemiology, 11, 231-252. https://doi.org/10.1038/sj.jea.7500165

[2] Salthammer, T. and Bahadir, M. (2009) Occurrence, Dynamics and Reactions of Organic Pollutants in the Indoor Environment. CLEAN-Soil Air Water, 37, 417-435. https://doi.org/10.1002/clen.200900015

[3] Alance, M., Gaidolfi, L., Pessina, V. and Dallara, G. (1996) Distribution of ${ }^{226} \mathrm{Ra}$, ${ }^{232} \mathrm{Th}$, and ${ }^{40} \mathrm{~K}$ in Soils of Rio Grande do Norte (Brazil). Journal of Environmental 
Radioactivity, 30, 55-67. https://doi.org/10.1016/0265-931X(95)00035-9

[4] United Nations Scientific Committee on the Effects of Atomic Radiation (UNSCEAR) (2000) Sources and Effects of Ionizing Radiation. United Nations, New York.

[5] United Nations Scientific Committee on the Effects of Atomic Radiation (UNSCEAR) (2006) Sources and Effects of Ionizing Radiation. United Nations, New York.

[6] Iyer, R.S. and Scott, J.A. (2001) Power Station Fly Ash-A Review of Value-Added Utilization outside of the Construction Industry. Resources, Conservation and Recycling, 31, 217-228. https://doi.org/10.1016/S0921-3449(00)00084-7

[7] Pantazopoulou, E., Zebiliadou, O., Bartzas, G., Xenidis, A., Zouboulis, A. and Komnitsas, K. (2015) Industrial Solid Waste Management in Greece: The Current Situation and Prospects for Valorization. Journal of Solid Waste Technology and Management, 41, 383-394.

[8] Radiological Protection Principles Concerning the Natural Radioactivity of Building Materials. https://ec.europa.eu/energy/sites/ener/files/documents/112.pdf

[9] Saravanan, S., Jodha, A.S., Gopalani, D., Bhati, S.S. and Kumar, S. (2003) Preliminary Measurements of Natural Radioactivity at Madurai District of Tamilnadu, India. Radiation Measurements, 36, 397-399. https://doi.org/10.1016/S1350-4487(03)00159-8

[10] Medhat, M.E. and Fayez-Hasssan, M. (2010) Natural Radioactivity of Egyptian Building Materials. Arab Journal of Nuclear Sciences and Applications, 43, 151-160.

[11] Szabó, Z., Völgyesi, P., Nagy, H.É., Szabó, C., Kis, Z. and Csorba, O. (2013) Radioactivity of Natural and Artificial Building Materials-A Comparative Study. Journal of Environmental Radioactivity, 118, 64-74. https://doi.org/10.1016/j.jenvrad.2012.11.008

[12] (2005) Genie 2000, Version 3.2. Canberra Industries, Inc., Canberra France HQ \& Europe Coordination Bois Mouton, Canberra.

[13] Boukhair, A., Belahbib, L., Azkour, K., Nebdi, H., Benjelloun, M. and Nourreddine, A. (2016) Measurement of Natural Radioactivity and Radon Exhalation Rate in Coal Ash Samples from a Thermal Power Plant. World Journal of Nuclear Science and Technology, 6, 153-160. https://doi.org/10.4236/wjnst.2016.63017

[14] Trevisi, R., Risica, S., D’Alessandro, M., Paradiso, D. and Nuccetelli, C. (2012) Natural Radioactivity in Building Materials in the European Union: A Database and an Estimate of Radiological Significance. Journal of Environmental Radioactivity, 105, 11-20. https://doi.org/10.1016/j.jenvrad.2011.10.001

[15] Yu, K.N., Guan, Z.J., Stokes, M.J. and Young, E.C.M. (1992) The Assessment of the Natural Radiation Dose Committed to the Hong Kong People. Journal of Environmental Radioactivity, 17, 31-48. https://doi.org/10.1016/0265-931X(92)90033-P

[16] Turhan, Ş., Baykan, U.N. and Şen, K. (2008) Measurement of the Natural Radioactivity in Building Materials Used in Ankara and Assessment of External Doses. Journal of Radiological Protection, 28, 83-91. https://doi.org/10.1088/0952-4746/28/1/005

[17] Lee, S.C., Kim, C.K., Lee, D.M. and Kang, H.D. (2001) Natural Radionuclides Contents and Radon Exhalation Rates in Building Materials Used in South Korea. Radiation Protection Dosimetry, 94, 269-274. https://doi.org/10.1093/oxfordjournals.rpd.a006499

[18] Shoeib, M.Y. and Thabayneh, K.M. (2014) Assessment of Natural Radiation Expo- 
sure and Radon Exhalation Rate in Various Samples of Egyptian Building Materials. Journal of Radiation Research and Applied Sciences, 7, 174-181. https://doi.org/10.1016/j.jrras.2014.01.004

[19] Al-Sulaiti, H., Alkhomashi, N., Al-Dahan, N., Al-Dosari, M., Bradley, D.A., Bukhari, S., Matthews, M., Regan, P.H. and Santawamaitre, T. (2001) Determination of the Natural Radioactivity in Qatarian Building Materials Using High-Resolution Gamma-Ray Spectrometry. Nuclear Instruments and Methods in Physics Research A, 652, 915-919. https://doi.org/10.1016/j.nima.2011.01.020

[20] Manić, G., Manić, V., Nikezić, D. and Krstić, D. (2015) The Dose of Gamma Radiation from Building Materials and Soil. NUKLEONIKA, 60, 951-958. https://doi.org/10.1515/nuka-2015-0148

[21] Najam, L.A., Tawfiq, N.F. and Kitah, F.H. (2013) Measurement of Natural Radioactivity in Building Materials Used in IRAQ. Australian Journal of Basic and Applied Sciences, 7, 56-66.

[22] El-Taher, A. (2012) Assessment of Natural Radioactivity Levels and Radiation Hazards for Building Materials Used in Qassim Area, Saudi Arabia. Romanian Journal of Physics, 57, 726-735.

[23] Rizzo, S., Brai, M., Basile, S., Bellia, S. and Hauser, S. (2001) Gamma Activity and Geochemical Features of Building Materials: Estimation of Gamma Dose Rate and Indoor Radon Levels in Sicily. Applied Radiation and Isotopes, 55, 259-265. https://doi.org/10.1016/S0969-8043(00)00384-5

[24] Mehdizadeh, S., Faghihi, R. and Sina, S. (2011) Natural Radioactivity in Building Materials in Iran. NUKLEONIKA, 56, 363-368.

[25] Xhixha, G., Ahmeti, A., Bezzon, G.P., Bitri, M., Broggini, C., Buso, G.P., Caciolli, A., Callegari, I., Cfarku, F., Colonna, T., Fiorentini, G., Guastaldi, E., Mantovani, F., Massa, G., Menegazzo, R., Mou, L., Prifti, D., Rossi Alvarez, C., Sadiraj Kuqi, Dh., Shyti, M., Tushe, L., Xhixha Kaçeli, M. and Zyfi, A. (2013) First Characterization of Natural Radioactivity in Building Materials Manufactured in Albania. Radiation Protection Dosimetry, 155, 217-223. https://doi.org/10.1093/rpd/ncs334

[26] Solak, S., Turhan, S., Ugur, F.A., Goren, E., Gezer, F., Yegingil, Z. and Yegingil, I. (2012) Evaluation of Potential Exposure Risks of Natural Radioactivity Levels Emitted from Building Materials Used in Adana, Turkey. Indoor and Built Environment, 23, 594-602. https://doi.org/10.1177/1420326X12448075

[27] Amrani, D. and Tahtat, M. (2001) Natural Radioactivity in Algerian Building Materials. Applied Radiation and Isotopes, 54, 687-689. https://doi.org/10.1016/S0969-8043(00)00304-3

[28] Tufail, M., Ahmad, N., Mirza, S.M., Mirza, N.M. and Khan, H.A. (1992) Natural Radioactivity from the Building Materials Used in Islamabad and Rawalpindi, Pakistan. The Science of the Total Environment, 121, 283-291. https://doi.org/10.1016/0048-9697(92)90321-I

[29] Hayambu, P., Zaman, M.B., Lubaba, N.C.H., Munsanje, S.S. and Muleya, D. (1995) Natural Radioactivity in Zambian Building Materials Collected from Lusaka. Journal of Radioanalytical and Nuclear Chemistry, 199, 229-238. https://doi.org/10.1007/BF02162371

[30] International Commission on Radiological Protection (1990) Recommendations of the International Commission on Radiological Protection. Annals of the ICRP, 21, 1-3.

[31] Pape, A., Adloff, J.C., Barillon, R., Haessler, A., Hoernel, A., Nourreddine, A., Oster, D. and Weidmann, D. (1998) Quantitative Alpha-Particle Detection in a Homoge- 
neous Medium with LR115. Nuclear Instruments and Methods in Physics Research Section B: Beam Interactions with Materials and Atoms, 143, 557-560. https://doi.org/10.1016/S0168-583X(98)00398-X

[32] Abu-Jarad, F., Fremlin, J.H. and Bull, R. (1980) A Study of Radon Emitted from Building Materials Using Plastic $\alpha$-Track Detectors. Physics Medicine and Biology, 25, 683-694. https://doi.org/10.1088/0031-9155/25/4/007

[33] Khan, A.J., Prasad, R. and Tyagi, R.K. (1992) Measurement of Radon Exhalation Rate from Some Buildings Materials. International Journal of Radiation Applications and Instrumentation. Part D. Nuclear Tracks and Radiation Measurements, 20, 609-610. https://doi.org/10.1016/1359-0189(92)90013-L

[34] International Commission on Radiological Protection (ICRP) (2014) Radiological Protection against Radon Exposure. Annals of the ICRP, 43, 3.

[35] Nain, M., Chauhan, R.P. and Chakarvarti, S.K. (2006) Alpha Radioactivity in Indian Cement Samples. Iranian Journal of Radiation Research, 3, 171-176.

[36] Ismail, A.M., Abumurad, K.M., Kullab, M.K. and Al-Bataina, B.A. (1994) Measurement of Rn-222 Concentrations in Building Materials Used in Jordan. Mutah Journal for Research and Studies, 28, 1119-1127.

[37] Dabayneh, K.M. (2008) ${ }^{222}$ Rn Concentration Level Measurements and Exhalation Rates in Different Types of Building Materials Used in Palestinian Buildings. Isotope and Radiation Research, 40, 278-289.

[38] Amin, R.M. (2015) A Study of Radon Emitted from Building Materials Using Solid State Nuclear Track Detectors. Journal of Radiation Research and Applied Sciences, 8, 516-522. https://doi.org/10.1016/j.jrras.2015.06.001

[39] Amrani, D. and Cherouati, D.E. (1999) Radon Exhalation Rate in Building Materials Using Plastic Track Detectors. Journal of Radioanalytical and Nuclear Chemistry, 242, 269-271. https://doi.org/10.1007/BF02345552

[40] Pereiraa, C.E., Vaidyana, V.K., Jojoa, P.J. and Ramachandran, T.V. (2008) Measurement of Radon Exhalation Rate from Building Materials Used in the Southwest Coastal Region of India. Indoor and Built Environment, 17, 472-475. https://doi.org/10.1177/1420326X08095830

[41] Saad, A.F., Hend, H., Al-Awami and Hussein, N.A. (2014) Radon Exhalation from Building Materials Used in Libya. Radiation Physics and Chemistry, 101, 15-19. https://doi.org/10.1016/j.radphyschem.2014.03.030 